\title{
Kecernaan Ransum Domba Berbasis Daun Sawit Teramoniasi yang Disuplementasi Sulfur, Fosfor, dan Daun Ubi Kayu
}

\author{
Digestibility of Sheep Ration Containing Ammoniated Palm Oil Leaves Supplemented with Sulphur, \\ Phosphor, and Cassava Leaves
}

\author{
Nurhaita $^{\text {* }}$, N. Jamarun ${ }^{\mathrm{b}}$, L. Warly ${ }^{\mathrm{b}}$, \& M. Zain ${ }^{\mathrm{b}}$ \\ aFakultas Pertanian, Universitas Muhammadiyah Bengkulu \\ Jln. Kampung Bali, Bengkulu \\ bFakultas Peternakan, Universitas Andalas \\ Kampus Limau Manis, Padang 25163 \\ (Diterima 19-06-2009; disetujui 13-12-2010)
}

\begin{abstract}
This research aimed to evaluate the effect of $S, P$ minerals and cassava leaves supplementation on utilization of ammoniated palm oil leaves in rumen sheep. The research used randomized block design with five rations as treatments and four groups as replication. The treatments were $\mathrm{A}=$ grass as control; $\mathrm{B}=$ ammoniated palm oil leaves; $\mathrm{C}=$ ammoniated palm oil leaves $+0.4 \% \mathrm{~S}$ and $0.27 \% \mathrm{P}$; $\mathrm{D}=$ ammoniated palm oil leaves $+5 \%$ cassava leaves; and $\mathrm{E}=$ ammoniated palm oil leaves $+\mathrm{y} 0.4 \% \mathrm{~S}$, $0.27 \% \mathrm{P}$ and $5 \%$ cassava leaves. The parameters measured were dry matter intake and digestibility of dry matter and fiber fraction (NDF, ADF, cellulose, and hemicelluloses). Dietary treatments had not significant effect on dry matter intake but significantly increased dry matter and fiber fraction digestibility, especially ADF. Diet E indicated the highest digestibility which supplied the entire nutrient required to growth and optimize activities of rumen microbes.
\end{abstract}

Key words: palm oil leaves, ammoniation, cassava leaves, digestibility, sheep

\section{PENDAHULUAN}

Potensi daun sawit cukup besar untuk dapat dimanfaatkan sebagai sumber pakan hijauan alternatif bagi ternak ruminansia. Luas perkebunan sawit di Indonesia sampai akhir tahun 2008 adalah 7,3 juta ha (BPS, 2009), dengan tingkat produksi daun sawit 17,1 ton bahan kering /ha tahun, sehingga dengan demikian akan dihasilkan daun sawit 124.830 .000 ton bahan kering/ahun. Jumlah tersebut cukup untuk memenuhi kebutuhan 26.307,69 unit ternak atau setara dengan 30.516,92 ekor sapi dewasa dengan berat $300 \mathrm{~kg}$ tahun. Namun demikian pemanfaatannya sebagai pakan ternak masih sangat terbatas. Hal ini antara lain disebabkan rendahnya kualitas gizi daun sawit. Menurut Djajanegara et al. (1999), kandungan lignin daun kelapa sawit cukup tinggi, yaitu 13,79\%, hal ini menyebabkan rendahnya kecernaan pada daun sawit. Daun sawit harus diolah terlebih dahulu agar nilai gizi dan kecernaannya meningkat, sehingga dapat dimanfaatkan secara optimal.

* Korespondensi:

Fakultas Pertanian, Universitas Muhammadiyah Bengkulu

Jln. Kampung Bali, Bengkulu

E-mail: nurhaita@gmail.com
Beberapa teknik pengolahan baik secara fisik, kimia, biologis maupun kombinasinya terbukti mampu meningkatkan nilai manfaat dari pakan limbah (Akbar, 2001; Akbar et al., 2005; Nurhaita, 2001; Nurhaita, 2007; Zain et al., 2006). Van Soest (2006) melaporkan terjadi peningkatan konsumsi dan kecernaan bahan kering ransum jerami amoniasi dibanding yang tidak pada ternak sapi. Perlakuan amoniasi pada daun sawit mengakibatkan peningkatan kecernaan secara in-vitro sebesar $13,1 \%$ dari 32,52\% menjadi 36,78\% (Nurhaita et al., 2007), namun angka kecernaan ini masih sangat kecil dan belum optimal untuk mendukung produktivitas ternak. Oleh karena itu untuk peningkatan kecernaan pakan serat selain upaya pengolahan juga harus dipadukan dengan upaya mengoptimalkan bioproses di dalam rumen melalui peningkatan populasi mikroba rumen karena kecernaan pakan serat dalam rumen sangat tergantung pada kerja enzim mikroba rumen.

Pertumbuhan mikroba yang optimal memerlukan ketersediaan nutrien yang cukup, seperti energi, nitrogen, asam-asam amino, mineral dan vitamin. Sulfur (S) dan fosfor (P) merupakan mineral yang esensial bagi mikroba pencerna serat. Mineral tersebut sering menjadi faktor pembatas bagi pertumbuhan mikroba rumen pada ternak yang mendapat pakan berserat kualitas rendah. Hal ini disebabkan pakan pada daerah tropis 
dan juga pakan yang berasal dari hasil ikutan pertanian atau perkebunan sering defisien dengan mineral penting untuk pertumbuhan mikroba seperti $\mathrm{S}$ dan $\mathrm{P}$ (Komisarczuk \& Durand, 1991), selain itu bioavailability mineral pada pakan serat ini juga rendah.

Mineral P dibutuhkan oleh semua mikroba terutama untuk menjaga integritas membran dan dinding sel, komponen asam nukleat dan bagian dari molekul berenergi tingggi (ATP, ADP, dan lain-lain) (Bravo et al., 2003; Rodehutscord et al., 2000). Mineral S merupakan unsur penting yang fungsi utamanya adalah untuk menyokong pembentukan asam amino yang mengandung sulfur dan sintesa protein mikroba, di samping itu juga penting untuk sintesa beberapa vitamin (tiamina dan biotin) serta koenzim (COASH) (Komisarczuk \& Durand, 1991). Defisiensi mineral S dan P akan berpengaruh terhadap degradasi komponen nutrien dan terhadap sintesis protein mikroba.

Penambahan S pada jerami padi yang diamoniasi dan tanpa amoniasi menunjukkan peningkatan sintesis mikroba dan kecernaan selulosa (Stevani et al., 2002; Zain et al., 2010). Penelitian Kennedy et al. (2000) memperlihatkan bahwa suplementasi P dalam bentuk fosfat secara in vitro mampu meningkatkan kecernaan NDF dari bagasse. Secara in-vitro suplementasi mineral $\mathrm{S}$ dan $\mathrm{P}$ pada daun sawit yang diamoniasi mampu meningkatkan kecernaannya sebesar 36,68\% dari 34,67\% menjadi 47,39\% (Nurhaita et al., 2008).

Selain mineral, bakteri selulolitik rumen juga membutuhkan asam lemak rantai bercabang (branched chain fatty acids= BCFA) yang terdiri atas asam isobutirat, 2 metil butirat dan asam valerat. BCFA ini adalah sumber rangka karbon bagi bakteri yang merupakan hasil dekarboksilasi dan deaminasi dari asam amino rantai bercabang (AARC). AARC dalam rumen sebagian besar berasal dari hasil fermentasi protein ransum dan mikroba rumen yang mengalami lisis. Bahan hasil ikutan pertanian yang berkualitas rendah seperti daun sawit pasokan AARC-nya sangat rendah sehingga diperlukan suplementasi AARC dalam ransum. Penambahan AARC, yaitu valina, isoleusina, dan leusina, mampu meningkatkan populasi mikroba rumen dan kecernaan serat sawit (Zain et al., 2007).

Sumber AARC alami yang murah dan mudah diperoleh adalah daun ubi kayu. Daun ubi kayu mengandung protein kasar cukup tinggi dengan kandungan asam amino iso valina $0,45 \%$, isoleusina $0,46 \%$, dan leusina $0,63 \%$ (Nurhaita, 2008). Suplementasi 5\% daun ubi kayu pada daun sawit teramoniasi yang disuplementasi dengan mineral S dan P dapat meningkatkan kecernaan bahan kering sebesar 24,09\% dan kecernaan ADF sebesar $44,35 \%$ secara in-vitro (Nurhaita, 2008). Penelitian Zain et al. (2003) juga memperlihatkan bahwa penggunaan tepung daun ubi kayu sebagai sumber asam amino bercabang (valina, leusina, dan isoleusina) pada pakan serat sawit teramoniasi mampu memperbaiki kecernaan pakan dan pertumbuhan ternak domba.

Bertitik tolak dari uraian di atas maka dilakukan penelitian untuk mengevaluasi pengaruh suplementasi mineral S, P, dan tepung daun ubi kayu pada daun sawit teramoniasi terhadap optimalisasi bioproses dalam rumen domba.

\section{MATERI DAN METODE}

\section{Bahan Penelitian}

Sebagai bahan penelitian digunakan 20 ekor domba jantan umur 6-10 bulan dengan bobot badan $10 \pm 3 \mathrm{~kg}$. Domba dikelompokkan berdasarkan berat badannya menjadi kelompok berat badan $12,5 \pm 0,5 \mathrm{~kg}, 10,5 \pm 0,5 \mathrm{~kg}$;

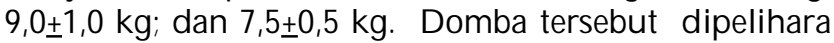
selama empat bulan di kandang percobaan dan dialokasikan secara acak pada lima macam ransum perlakuan. Ransum terdiri atas hijauan dan konsentrat dengan perbandingan 50\%:50\% (Tabel 1, 2, dan 3). Konsentrat disusun dari dedak halus, bungkil kelapa, garam dan kapur, sedangkan hijauan terdiri atas rumput lapangan untuk kontrol dan daun sawit teramoniasi dengan suplementasi mineral S, P, dan tepung daun ubi kayu.

\section{Metode Penelitian}

Percobaan menggunakan rancangan acak kelompok, dengan lima perlakuan ransum dan empat kelompok domba sebagai ulangan. Setiap ulangan terdiri atas satu ekor domba. Perlakuan yang diuji adalah 5 macam ransum yang terdiri atas: $\mathrm{A}=$ rumput lapangan + konsentrat (50\%:50\%) sebagai kontrol; $B=$ daun kelapa sawit teramoniasi + konsentrat (50\%:50\%); C= B + 0,4\% S dan $0,27 \% \mathrm{P} ; \mathrm{D}=\mathrm{B}+5 \%$ tepung daun ubi kayu; dan $\mathrm{E}=\mathrm{B}+$ 0,4\% S, 0,27\% P dan 5\% tepung daun ubi kayu.

Peubah yang diamati adalah konsumsi ransum (g/ ekor/hari) dan kecernaan nutrien (\%). Kecernaan nutrien ditentukan dengan metode koleksi total. Semua data yang diperoleh dianalisa dengan analisis sidik ragam (analysis of variance) dan perbedaan antar perlakuan diuji dengan uji Duncan multiple range test (DMRT) (Steel \& Torrie, 1991).

Tabel 1. Susunan bahan penyusun ransum domba penelitian (\% BK)

\begin{tabular}{lccccc}
\hline \multirow{2}{*}{ Bahan makanan } & \multicolumn{5}{c}{ Ransum perlakuan } \\
\cline { 2 - 6 } & $\mathrm{A}$ & $\mathrm{B}$ & $\mathrm{C}$ & $\mathrm{D}$ & $\mathrm{E}$ \\
\hline Rumput lapangan & 50 & 0 & 0 & 0 & 0 \\
$\begin{array}{l}\text { Daun sawit } \\
\text { teramoniasi }\end{array}$ & 0 & 50 & 50 & 50 & 50 \\
Dedak halus & 40 & 40 & 40 & 40 & 40 \\
Bungkil kelapa & 9,5 & 9,5 & 9,5 & 9,5 & 9,5 \\
Garam & 0,25 & 0,25 & 0,25 & 0,25 & 0,25 \\
Kapur & 0,25 & 0,25 & 0,25 & 0,25 & 0,25 \\
Jumlah & 100 & 100 & 100 & 100 & 100 \\
Suplementasi & & & & & \\
* Sulfur & 0 & 0 & 0,4 & 0 & 0,4 \\
* Fosfor & 0 & 0 & 0,27 & 0 & 0,27 \\
* Daun ubi kayu & 0 & 0 & 0 & 5 & 5 \\
\hline
\end{tabular}

Keterangan: $A=$ rumput lapangan + konsentrat (50\%:50\%) sebagai kontrol; $\mathrm{B}=$ daun kelapa sawit teramoniasi + konsentrat (50\%:50\%); $\mathrm{C}=\mathrm{B}+0,4 \% \mathrm{~S}$ dan $0,27 \% \mathrm{P} ; \mathrm{D}=\mathrm{B}+5 \%$ tepung daun ubi kayu; dan $\mathrm{E}=\mathrm{B}+0,4 \% \mathrm{~S}, 0,27 \% \mathrm{P}$ dan $5 \%$ tepung daun ubi kayu. 
Tabel 2. Komposisi kimia bahan penyusun ransum domba penelitian (\% BK)

\begin{tabular}{lcccc}
\hline Nutrien & Rumput & DSA & TDUK & Konsentrat \\
\hline Bahan kering & 20,16 & 43,31 & 82,82 & 86,26 \\
Bahan organik & 91,04 & 85,72 & 91,62 & 85,05 \\
Serat kasar & 25,63 & 22,91 & 19,73 & 20,99 \\
Protein kasar & 13,00 & 14,08 & 17,52 & 11,74 \\
Lemak kasar & 1,97 & 3,61 & 6,42 & 5,53 \\
BETN & 56,82 & 56,4 & 54,33 & 57,23 \\
NDF & 63,19 & 57,42 & 37,28 & 41,2 \\
ADF & 41,2 & 44,42 & 35,33 & 23,76 \\
Selulosa & 31,58 & 19,76 & 26,48 & 16,02 \\
Hemiselulosa & 21,99 & 13,00 & 1,95 & 17,44 \\
Lignin & 8,42 & 16,57 & 4,50 & 3,75 \\
Sulfur* & 0,33 & 0,40 & 0,42 & 0,23 \\
Fosfor* & 0,46 & 0,06 & 0,39 & 0,84 \\
Valina\# & - & 0,58 & 0,45 & 0,38 \\
Isoleusina\# & - & 0,32 & 0,46 & 0,22 \\
Leusina\# & - & 0,59 & 0,63 & 0,39 \\
\hline
\end{tabular}

Keterangan: Hasil analisis Laboratorium Gizi Ruminansia Fakultas Peternakan, Universitas Andalas (2007); *Hasil analisis Laboratorium Tanah, Tanaman dan Air, BPTP Sumbar (2007); "Hasil analisis PT. Saraswanti Indo Genetech, Bogor (2006). DSA= daun sawit teramoniasi; TDUK= tepung daun ubi kayu.

Tabel 3. Komposisi kimia ransum perlakuan domba penelitian (\% BK)

\begin{tabular}{lrrrrr}
\hline & \multicolumn{5}{c}{ Ransum perlakuan } \\
\cline { 2 - 6 } Nutrien & \multicolumn{1}{c}{$\mathrm{A}$} & \multicolumn{1}{c}{$\mathrm{B}$} & \multicolumn{1}{c}{$\mathrm{C}$} & \multicolumn{1}{c}{$\mathrm{D}$} & \multicolumn{1}{c}{$\mathrm{E}$} \\
\hline Bahan kering & 53,21 & 64,79 & 64,79 & 68,92 & 68,92 \\
Bahan organik & 88,05 & 85,39 & 85,39 & 89,97 & 89,97 \\
Serat kasar & 23,31 & 21,95 & 21,95 & 22,94 & 22,94 \\
Protein kasar & 12,37 & 12,91 & 12,91 & 13,79 & 13,79 \\
Lemak kasar & 3,75 & 4,57 & 4,57 & 4,89 & 4,89 \\
BETN & 57,02 & 56,81 & 56,81 & 54,52 & 54,52 \\
NDF & 52,20 & 49,31 & 49,31 & 51,17 & 51,17 \\
ADF & 32,48 & 34,09 & 34,09 & 35,86 & 35,86 \\
Selulosa & 23,80 & 17,89 & 17,89 & 19,21 & 19,21 \\
Hemiselulosa & 19,71 & 15,22 & 15,22 & 15,32 & 15,32 \\
Sulfur & 0,28 & 0,32 & 0,57 & 0,34 & 0,60 \\
Fosfor & 0,65 & 0,45 & 0,62 & 0,45 & 0,64 \\
Valina & - & 0,48 & 0,48 & 0,50 & 0,50 \\
Isoleusina & - & 0,27 & 0,27 & 0,29 & 0,29 \\
Leusina & - & 0,49 & 0,49 & 0,52 & 0,52 \\
\hline
\end{tabular}

Keterangan: dihitung berdasarkan Tabel 1 dan 2. A= rumput lapangan + konsentrat (50\%:50\%) sebagai kontrol; $\mathrm{B}=$ daun kelapa sawit teramoniasi + konsentrat $(50 \%: 50 \%) ; C=B+0,4 \%$ S dan $0,27 \% \mathrm{P} ; \mathrm{D}=\mathrm{B}+5 \%$ tepung daun ubi kayu; dan $\mathrm{E}=\mathrm{B}+$ $0,4 \%$ S, $0,27 \%$ P dan $5 \%$ tepung daun ubi kayu.

\section{HASIL DAN PEMBAHASAN}

\section{Konsumsi Ransum}

Konsumsi merupakan tolok ukur penilaian palatabilitas suatu bahan pakan. Perlakuan ransum tidak mempengaruhi konsumsi bahan kering $(\mathrm{P}>0,05)$. Konsumsi bahan kering pada penelitian ini berkisar 307-376 g/ekor/hari. Meskipun konsumsi bahan kering berbeda tidak nyata, namun konsumsi bahan kering pada suplementasi tepung daun ubi kayu (ransum D) cenderung lebih tinggi, yaitu 376 g/ekor/hari dari perlakuan lainnya (Tabel 4).

Perlakuan nampaknya tidak mempengaruhi palatabilitas ransum, hal ini tercermin dari konsumsi bahan kering yang hampir sama. Keadaan ini sebagai akibat dari komposisi dan kandungan nutrien dalam ransum yang hampir sama (Tabel 3). Selain itu bentuk fisik, ukuran partikel pakan dan frekuensi pemberian pakan juga mempengaruhi konsumsi pakan. Hijauan yang diberikan pada penelitian ini telah dipotongpotong terlebih dahulu, sehingga bentuk fisik dan ukuran partikelnya hampir sama. Frekuensi pemberian ransum dilakukan 3 kali, yaitu pagi konsentrat, siang dan sore hijauan, dengan demikian ternak percobaan mempunyai waktu yang sama untuk mengkonsumsi sejumlah pakan yang diberikan. Ternak domba yang digunakan dalam penelitian ini berumur 6-10 bulan yang merupakan periode pertumbuhan dengan bobot badan $10 \pm 3 \mathrm{~kg}$. Hal ini berarti kapasitas alat pencernaan dan kebutuhan nutriennya juga hampir sama. Tingkat konsumsi pakan dipengaruhi oleh kandungan nutrisi pakan, ukuran partikel pakan, jumlah kalori, disamping itu juga dipengaruhi oleh bangsa ternak, bobot badan, umur, laju produksi, kegemukan ternak, kandungan protein dan kalori pakan, metabolisme dalam darah dan rumen, kondisi fisiologis, dan nilai kecernaan pakan.

Konsumsi bahan kering pada penelitian ini berkisar antara $51,06-57,94 \mathrm{~g} / \mathrm{kg} \mathrm{W}^{0,75}$ atau 2,80\%-3,13\% dari bobot badan (Tabel 4). Nilai ini hampir sama dengan yang diperoleh Akbar (2006) yang mendapatkan konsumsi bahan kering sebesar 2,5\%-3,66\% dari bobot badan pada ternak domba menggunakan tandan kosong sawit fermentasi. Akbar (2001) yang memberikan serat sawit fermentasi pada ternak domba mendapatkan konsumsi bahan kering sebesar 61,61-73,88 g/kg W $\mathrm{W}^{0,75}$ atau 3,01\%$5,56 \%$ dari bobot badan. Data konsumsi menunjukkan bahwa daun kelapa sawit yang diamoniasi dan diberikan kepada domba mempunyai palatabilitas yang sama seperti rumput lapang. Penambahan daun ubi kayu dan suplementasi S dan P tidak dapat meningkatkan palatabilitas daun kelapa sawit teramoniasi.

\section{Kecernaan Nutrien}

Kecernaan pakan pada ternak ruminansia sangat erat hubungannya dengan jumlah dan aktivitas mikroba dalam rumen. Nilai kecernaan nutrien daun sawit yang diamoniasi (perlakuan B) nyata lebih rendah dibandingkan perlakuan lainnya (Tabel 5). Hal ini merupakan gambaran rendahnya aktivitas dan jumlah mikroba di dalam rumen. Walaupun pada perlakuan ini amonia 
Tabel 4. Rata-rata konsumsi bahan kering ransum penelitian

\begin{tabular}{lrrrrrr}
\hline \multirow{2}{*}{ Konsumsi BK } & \multicolumn{1}{c}{ Perlakuan } & \multicolumn{1}{c}{ SE } \\
\cline { 2 - 6 } & \multicolumn{1}{c}{ A } & \multicolumn{1}{c}{ B } & \multicolumn{1}{c}{ C } & \multicolumn{1}{c}{ D } & E & \\
\hline g/ekor/hari & 321,06 & 325,10 & 307,25 & 375,79 & 315,18 & 15,10 \\
g/kg W0.75 & 51,42 & 55,16 & 51,06 & 57,94 & 54,41 & 1,72 \\
\% BB & 2,80 & 3,07 & 2,83 & 3,13 & 3,05 & 0,09 \\
\hline
\end{tabular}

Keterangan: Superskrip yang berbeda pada baris yang sama menunjukkan berbeda nyata $(\mathrm{P}<0,05)$. A= rumput lapangan + konsentrat $(50 \%: 50 \%)$ sebagai kontrol; $\mathrm{B}=$ daun kelapa sawit teramoniasi + konsentrat $(50 \%: 50 \%) ; \mathrm{C}=\mathrm{B}+0,4 \% \mathrm{~S}$ dan $0,27 \% \mathrm{P} ; \mathrm{D}=\mathrm{B}+5 \%$ tepung daun ubi kayu; dan $\mathrm{E}=\mathrm{B}+0,4 \% \mathrm{~S}, 0,27 \% \mathrm{P}$ dan $5 \%$ tepung daun ubi kayu.

yang tersedia dari pakan cukup tinggi, namun belum mampu meningkatkan pertumbuhan bakteri dalam rumen akibat tidak cukup tersedianya nutrien lain untuk pertumbuhan mikroba. Hal ini membuktikan bahwa untuk tumbuh baik bakteri dalam pakan berupa daun sawit teramoniasi tidak hanya membutuhkan nitrogen saja tetapi harus diikuti dengan penambahan nutrisi lain seperti energi, mineral dan asam amino. Suplementasi mineral S dan $\mathrm{P}$ (pada ransum $\mathrm{C}$ ) mampu meningkatkan kecernaan nutrien. Hal ini disebabkan suplementasi mineral $\mathrm{S}$ dan $\mathrm{P}$ telah menyebabkan terjadinya perbaikan kondisi rumen, sehingga meningkatkan pertumbuhan dan aktivitas mikroba rumen.

Kecernaan bahan kering pada ransum $C$ meningkat sebesar $8,71 \%$ dibanding ransum $\mathrm{B}$, sementara kecernaan fraksi serat NDF, ADF, dan selulosa meningkat masing-masing 8,93\%, 20,10\%, dan 5,44\%, tetapi kecernaan hemiselulosa tidak meningkat. Suplementasi mineral S dan P memberikan pengaruh positif terhadap kecernaan fraksi serat terutama ADF. Balt \& Ozturk (2006) melaporkan bahwa S penting bagi pencernaan serat di dalam rumen, suplai $S$ yang cukup dapat mengoptimalkan kecernaan selulosa melalui stimulasi spesifik bakteri selulolitik, defisiensi $S$ akan menghambat pertumbuhan mikroba rumen dan degradasi dinding sel tanaman (Karsli \& Russell, 2001). Mineral P secara spesifik dibutuhkan untuk kecernaan unsur utama dinding sel, terutama untuk selulolisis yang memerlukan $P$ lebih tinggi dibandingkan untuk hemiselulolisis dan amilolisis (Komisarczuk \& Durand, 1991). Defisiensi P memperlihatkan pengaruh negatif terhadap kecernaan fraksi serat dan kemampuan mencerna bahan organik pada kebanyakan studi in-vivo.

Suplementasi tepung daun ubi kayu pada ransum D secara nyata meningkatkan kecernaan nutrien. Peningkatan kecernaan bahan kering, NDF, ADF, dan selulosa pada ransum D masing-masing adalah sebesar $10,13 \%$; $15,83 \%$; $51,19 \%$; dan $43,12 \%$ tetapi terjadi penurunan kecernaan hemiselulosa sebesar $10,58 \%$. Tepung daun ubi kayu adalah sumber asam amino rantai bercabang. Asam amino bercabang merupakan sumber kerangka karbon yang dibutuhkan untuk menstimulasi pertumbuhan bakteri selulolitik. Tanpa kerangka karbon, amonia tidak bisa digunakan untuk sintesis protein mikroba rumen. Meningkatnya populasi dan aktivitas bakteri selulolitik juga tercermin pada peningkatan kecernaan ADF dan selulosa ransum. Hal yang serupa juga dilaporkan oleh Zain et al. (2003). Kondisi ini membuktikan bahwa bakteri selulolitik sangat responsif terhadap penambahan kerangka karbon bercabang. Penelitian ini menunjukkan bahwa mikroba rumen lebih responsif pada penambahan asam amino rantai cabang dibandingkan penambahan mineral S dan P. Hal ini tercermin dari peningkatan kecernaan nutrien yang lebih tinggi pada ransum $\mathrm{D}$ dibanding ransum $\mathrm{C}$.

Suplementasi mineral S dan P bersamaan dengan tepung daun ubi kayu pada ransum E menyebabkan kecernaan ransum meningkat sehingga menyamai

Tabel 5. Kecernaan nutrien ransum penelitian (\%)

\begin{tabular}{|c|c|c|c|c|c|c|}
\hline \multirow{2}{*}{ Kecernaan } & \multicolumn{5}{|c|}{ Ransum perlakuan } & \multirow{2}{*}{ SE } \\
\hline & A & B & $\mathrm{C}$ & $\mathrm{D}$ & $\mathrm{E}$ & \\
\hline Bahan kering & $61,59^{a}$ & $51,51^{\mathrm{c}}$ & $56,00^{\mathrm{bc}}$ & $56,73^{\mathrm{ab}}$ & $59,05^{a}$ & 1,47 \\
\hline Bahan organik & $64,57^{a}$ & $54,43^{c}$ & $58,42^{\mathrm{b}}$ & $59,74^{\mathrm{b}}$ & $61,61^{\mathrm{ab}}$ & 1,39 \\
\hline Serat kasar & $53,04^{a}$ & $48,69^{\mathrm{b}}$ & $51,63^{a}$ & $55,44^{a}$ & $55,36^{a}$ & 0,94 \\
\hline Protein kasar & $71,06^{\mathrm{a}}$ & $49,20^{c}$ & $56,45^{b}$ & $58,64^{\mathrm{b}}$ & $63,52^{b}$ & 2,32 \\
\hline NDF & $53,83^{a}$ & $42,21^{\mathrm{c}}$ & $45,98^{\mathrm{bc}}$ & $48,90^{\mathrm{ab}}$ & $51,84^{\mathrm{a}}$ & 1,69 \\
\hline $\mathrm{ADF}$ & $39,68^{\mathrm{a}}$ & $22,66^{c}$ & $27,21^{\mathrm{bc}}$ & $34,26^{\mathrm{ab}}$ & $41,02^{\mathrm{a}}$ & 2,89 \\
\hline Selulosa & $52,81^{b}$ & $43,73^{c}$ & $46,05^{\mathrm{bc}}$ & $62,59^{\mathrm{a}}$ & $52,35^{\mathrm{b}}$ & 2,24 \\
\hline Hemiselulosa & $76,92^{\mathrm{b}}$ & $86,49^{a}$ & $86,84^{a}$ & $77,34^{\mathrm{b}}$ & $89,56^{\mathrm{a}}$ & 2,46 \\
\hline
\end{tabular}

Keterangan: Superskrip yang berbeda pada baris yang sama menunjukkan berbeda nyata $(\mathrm{P}<0,05)$. A= rumput lapangan + konsentrat $(50 \%: 50 \%)$ sebagai kontrol; $\mathrm{B}=$ daun kelapa sawit teramoniasi + konsentrat (50\%:50\%); $\mathrm{C}=\mathrm{B}+0,4 \% \mathrm{~S}$ dan $0,27 \% \mathrm{P} ; \mathrm{D}=\mathrm{B}+5 \%$ tepung daun ubi kayu; dan $\mathrm{E}=\mathrm{B}+0,4 \% \mathrm{~S}, 0,27 \% \mathrm{P}$ dan $5 \%$ tepung daun ubi kayu. 
ransum A (rumput) (Tabel 5). Peningkatan kecernaan bahan kering, NDF, ADF, dan selulosa pada perlakuan E berturut-turut $14,63 \% ; 22,81 \% ; 81,05 \%$; dan $19,72 \%$ dibandingkan dengan perlakuan $\mathrm{B}$, yaitu ransum daun sawit amoniasi tanpa suplementasi mineral dan tepung daun ubi kayu. Peningkatan kecernaan ini sejalan dengan peningkatan sintesis protein mikroba (Nurhaita et al., 2010). Hal ini menunjukkan adanya peningkatan populasi dan aktivitas mikroba dalam rumen karena tersedianya nutrien untuk pertumbuhannya secara cukup dan seimbang. Hasil penelitian ini membuktikan bahwa suplementasi nutrien tertentu harus disesuaikan dengan ketersediaan nutrien lainnya. Peningkatan kecernaan terbaik dapat dicapai pada ransum yang mengandung semua nutrien yang dibutuhkan oleh mikroba rumen, dalam hal ini nitrogen berasal dari amonia pada daun sawit amoniasi, mineral sulfur dan fosfor dari suplementasi mineral dan kerangka karbon bercabang berasal dari asam amino rantai bercabang yang terkandung dalam tepung daun ubi kayu. Suplementasi mineral S dan P dan tepung daun ubi kayu pada penelitian ini terlihat memberikan pengaruh positif terhadap kecernaan terutama ADF.

Kecernaan bahan kering pada penelitian ini berkisar 51,51\%-61,59\% dan kecernaan ADF berkisar $22,66 \%-41,02 \%$. Angka tersebut sedikit lebih rendah dari pada kecernaan bahan kering dan ADF yang diperoleh Akbar (2007) yang menggunakan tandan kosong sawit fermentasi pada ternak domba, yaitu 60,12\%-70,97\% untuk kecernaan BK dan 36,44\%-56,47\% untuk kecernaan ADF. Hal ini disebabkan karena perbedaan kualitas ransum yang diberikan. Angka kecernaan ADF pada penelitian ini hampir sama dengan yang diperoleh Zain et al. (2007) yang mendapatkan kecernaan ADF sebesar $10,98 \%-51,09 \%$ pada domba defaunasi yang diberikan sabut sawit amoniasi, yang disuplementasi dengan analog hidroksi metionina dan asam amino rantai bercabang.

\section{KESIMPULAN}

Suplementasi mineral S, P dan daun ubi kayu pada penggunaan daun sawit yang diamoniasi dalam ransum domba tidak mempengaruhi konsumsi ransum, tetapi dapat meningkatkan optimalisasi bioproses dalam rumen yang tercermin dari peningkatan kecernaan bahan kering dan fraksi serat terutama ADF.

\section{DAFTAR PUSTAKA}

Akbar, S. A. 2001. Pengaruh pemberian serat sawit yang diolah dengan $\mathrm{NaOH}$ dan difermentasi dengan Aspergillus niger terhadap kecernaan ternak domba. Jurnal Peternakan dan Lingkungan Edisi Khusus April 2001

Akbar, S. A., N. Jamarun, R. Saladin, \& Mardiati Z. 2005. Pengaruh fermentasi dan defaunasi tandan kosong sawit terhadap kandungan gizi, kecernaan dan karakteristik cairan rumen in-vitro. Jurnal Ilmiah Ilmu-ilmu Peternakan VIII: 132-144.

Akbar, S. A. 2006. Pengaruh tandan kosong sawit fermentasi defaunasi dan by pass protein terhadap kecernaan ternak domba. Jurnal Ilmiah Ilmu-ilmu Peternakan IX: 205-213.

Akbar, S. A. 2007. Pemanfaatan tandan kosong sawit fermen- tasi yang dikombinasikan dengan defaunasi dan protein by pass rumen terhadap performan ternak domba. Jurnal Pengembangan Peternakan Tropis XXXII: 80-85.

Balt \& Ozturk. 2006. Effect of Sulfur containing supplements on ruminal fermentation and microbial protein synthesis. Research Journal of Anim. and Veterinary Sciences 1: 33-36.

Biro Pusat Statistik. 2009. Sumatera Barat dalam Angka 2008. Badan Pusat Statistik Propinsi Sumatera Barat, Padang

Bravo, D., D. Sanvant, C. Bogaert, \& F. Meschy. 2003. Quantitative aspect of phosphorus absorbtion in ruminant. Reprod Nutr. Dev. 43: 271-284.

Djajanegara, A., B. Sudaryanto, M. Winugroho, \&A. R. A. Karto. 1999. Potensi produk kebun kelapa sawit untuk pengembangan usaha ternak ruminansia. Laporan APBN 1998/1999. Balai Penelitian Ternak, Bogor.

Karsli, M. A. \& J. R. Russell. 2001. Effect of some dietary factors on ruminal microbial protein synthesis. J. Vet. Anim. Sci. 25: 681-685.

Kennedy, P. M, J. B. Lowry, \& L. I. Conlan. 2000. Phosphat rather than surfactant accounts for the main contribution to enhanced fibre digestibility resulting from treatmen with boiling neutral detergent. Anim. Feed Sci. Tech. 86: 177-170.

Komisarczuk, S. \& M. Durand. 1991. Effect of Mineral on Microbial Metabolism. In: J.P. Jouany (Ed). Rumen Microbial Metabolism and Ruminant Digestion. INRA Publ., Versailes.

Nurhaita. 2001. Daya cerna in-vitro dan karakteristik cairan rumen ternak domba akibat pemberian serat sawit yang telah diolah dengan $\mathrm{NaOH}$ dan difermentasi dengan Aspergillus niger. Jurnal Peternakan dan Lingkungan Edisi Khusus April 2001

Nurhaita. 2007. Efek beberapa metoda pengolahan terhadap kecernaan daun sawit amoniasi dan karakteristik cairan rumen in-vitro. Jurnal Sigmatek 1: 61-68.

Nurhaita, N. Jamarun, R. Saladin, L Warly, \& Mardiati Z. 2007. Efek beberapa metoda pengolahan limbah daun kelapa sawit terhadap kandungan gizi dan kecernaan secara in-vitro. J. Ilmu-Ilmu Pertanian Indonesia No 2: 139-144.

Nurhaita, N. Jamarun, R. Saladin, L Warly, \& Mardiati Z. 2008. Efek suplementasi mineral Sulfur dan Phospor pada daun sawit amoniasi terhadap kecernaan zat makanan secara in-vitro dan karakteristik cairan rumen. J. Pengembangan Peternakan Tropis 33: 51-58.

Nurhaita. 2008. Evaluasi dan pemanfaatan daun kelapa sawit dalam ransum ternak ruminansia. Disertasi. Program Pascasarjana Universitas Andalas, Padang.

Nurhaita, N. Jamarun, L Warly, \& Mardiati Z. 2010. Sintesis protein mikroba pada domba yang mendapat ransum daun sawit amoniasi yang disuplementasi mineral S,P dan daun ubi kayu. Jurnal Penelitian Universitas Jambi Seri Sains. 12: 107-114

Rodehutscord, M., Heuvers, \& H. Pfeffer. 2000. Effect of organic matter digestibility on obligatory faecal phosphorus loss in lactating goats, detyermined from balance data. J. Anim. Sci. $70: 561-568$

Stevani, J., M. Durand, R. Zanchi, Ph. Beaumatin, \& G. Hannequart. 2002. Effect of sulphate supplementation of untreated and alkali treated wheat straws on ruminal fermentition and microbial protein synthesis an a semi continous fermentor. Anim. Feed Sci. Technol. 36 :287-301.

Steel, R. G. \& J. H. Torrie. 1991. Prinsip dan Prosedur Statistik, Suatu Pendekatan Biometrik. Edisi 2. Alih Bahasa B. Sumantri. PT. Gramedia Pustaka Utama, Jakarta.

Van Soest, P. J. 2006. Rice straw the role of silica and treatment to improve quality. J. Anim. Feed. Sci Technol. 130: 137-171.

Zain, M., Elihasridas, \& Dj. Mangunwidjaya. 2003. Efek 
suplementasi daun ubi kayu terhadap kecernaan dan fermentabilitas (in-vitro) ransum berpakan serat sawit amoniasi urea. J. Andalas No. 41

Zain, M., Jamarun, Suryahadi, \& Nurhaita. 2006. Fermentabilitas dan kecernaan in-vitro serbuk sabut kelapa yang difermentasi dengan mikroba rumen. Jurnal Ilmiah Ilmu-ilmu Peternakan IX: 39-49.

Zain, M., Dj. Mangunwidjaya, \& Elihasridas. 2007. Optimalisasi penggunaan serat sawit sebagai pakan alter- natif dengan suplementasi daun ubi kayu dalam ransum ternak rumiansia (Supplementation of cassava leaves to optimaze the use palm press fiber as ruminant feed). J. Pengembangan Peternakan Tropis 32

Zain, M., N. Jamarun, \& Nurhaita. 2010. Effect of sulfur suplementation on in vitro fermentability and degradability of ammoniated rice straw. Pakistan Journal of Nutrition 9: 413-415. 